\title{
Platsernas eufori \\ (Ur den dolda bloggen om sömnlöshet)
}

\section{Vasilis Papageorgiou}

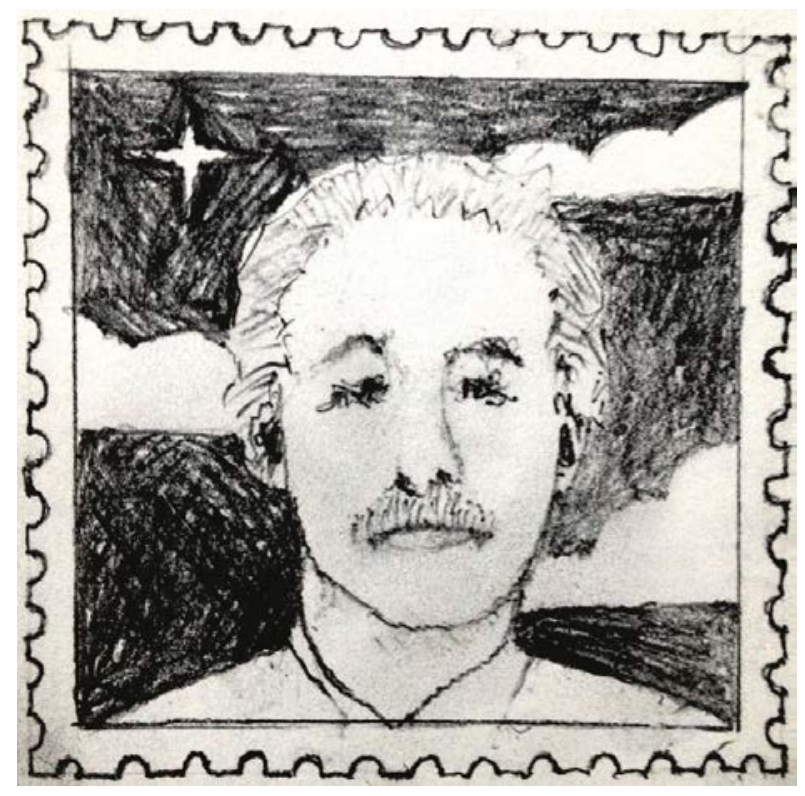

Sebald.

Illustration av Lo Snöfall.

Till Peter Luthersson

\section{Boston, 24 november 2011.}

"Den stora euforin att vara ensam" skulle kunna vara flanörens korta hälsning till Edgar Allan Poe som i sin berättelse "The man of the crowd" citerar Jean de la Bruyères ord "Ce grand malheur, de ne pouvoir être seul" ("Den stora olyckan att inte kunna vara ensam”). Men även titeln till dessa anteckningar, inspirerad (med hjälp av ett litet hopp i tankegången) av den amerikanske författaren, kunde ha varit "W. G. Sebald, platsernas man." Sebald djupt inne på de platser han skrev om, inte identifierad med dem och inte heller helt uppslukad av dem. Ett litet men distinkt avstånd skiljer flanören från den plats där han vandrar, ett avstånd som ett tunt moln som gör varje kontakt med det nya mjuk och vänlig, en nebulös formation som samtidigt är en klarhet, den som föder de självförkunnade mötena med det helt nya. Dessa mötens flöde i en ny stad, ett nytt landskap, är ofrånkomligen sammanflätat med platsernas, öppenhetens och den diskreta generositetens eufori. Det är bejakelsens eufori, i vilken ontologin upplöses och skingrar sig som damm, medan negationerna och allt det onda som de har belamrat historien, minnet och människans medvetenhet med begränsas till en liten men alltid väl åskådliggjord vrå i den obegränsade världen. 


\section{Cambridge, Mass., 27 mars 2012.}

Denna förväntansfulla eufori på de platser (mörka, sorgsna, förstörda) som Sebalds ensamme berättare reser genom eller beskriver ("Le promeneur solitaire” är titeln på hans essä om Robert Walser i volymen Logis in einem Landhaus). Geografiska och historiska platser, ämnen som diskuteras i detalj och ämnen som avlöser varandra utan förvarning. Flanörens spontana riktningar i staden eller på landet. Något drar hans uppmärksamhet, något talar till hans intuition, något som kan definieras eller något helt obestämbart. Flanören går planlöst och med hjälp av det planlösa går han vilse samtidigt som han oavlåtligen gör nya upptäckter. Framför allt går han. En dag sätter han igång någonstädes och går någonvart. En dag sätter Sebalds läsare igång och vandrar in i författarens texter och i deras intertextualitet. Läsaren förkroppsligar en episk rörelse, följer fötternas funderingar, kroppens betraktelser i tid och rum. En förtrogen rörelse mitt i det euforiskt oförtrogna, det fyllda av lyckliga avvikelser, tillfälligheter och sammanträffanden. Här följer en allitterativ tillfällighet: titeln Logis in einem Landhaus (Walsers ord dessa som vi skulle kunna återge som "Logi på ett lantställe") fick mig att tänka på berättelsen "Landor's cottage" ("Landors lantställe"), där fantasin blandas med (auto)biografin. Ett landskap som jag en gång hade farit över, rymligheten i minnet av det. De första raderna i Poes lilla berättelse: "Under en fotvandring i somras genom ett eller två flodkorsade distrikter i New York...” Detta initiala löfte om äventyr, upptäckter och avslöjanden i så många av Sebalds texter också. Löftet om aktiv njutning, mottagandet av en självverkande generositet, skingrandet av jaget i en oändlig öppenhet. Och det ofördröjliga fördubblandet av den första euforin då ett annat sätt att vandra avslöjas, som framkallar en annan känsla, ett annat intellekt och ett annorlunda förhållande till tiden. Huvudsakligen förfluten tid hos Sebald, minnenas arkiv ('Jag kan säga med ännu större säkerhet - och det är förknippat med berättarens melankoliska sinnelag - att de döda intresserar mig mer än de levande" ("Echoes from the past: A conversation with Piet de Moor", Jo Catling och Richard Hibbitt, Saturn's moons: W. G. Sebald - A handbook, 2011, s. 354). Övervägande närvarande tid hos Poe, den omedelbara erfarenheten. Intensiv inlevelse hos Poe, nykter distans hos Sebald. Båda bringar fram former av det okända och det oväntade. Vi kan väl då inte undra att vi i Saturn’s Moons (s. 406) läser att Sebald i sitt bibliotek hade Poes bok Tales of mystery and imagination, den gamla utgåvan från 1912 dessutom - som från minnets avlagringar - från förlaget Dent (Everyman).

\section{Cambridge, Mass., 29 mars 2012.}

Sebalds berättare är vända mot det förflutna, besvikna på historien eller bergtagna av främst personliga händelser i den, såsom det framgår till exempel av den för berättaren skrämmande scenen i "den blå bussen" (Svindel. Känslor, i W. G. Sebald, Dikt, prosa, essä. Övers. Ulrika Wallenström, 2011, s. 161. "Ja, denna specifika episod har faktiskt ägt rum som den beskrivs, och det är från den tiden som jag alltid har en av dessa små kameror i fickan", berättar Sebald i sitt samtal med Joseph Cuomo i boken The emer- 
gence of memory: Conversations with W. G. Sebald, red. Lynne Sharon Schwartz, 2007, s. 116-117) med tvillingbröderna som såg ut som Kafka eller av berättarens fruktsamma relation till Jacques Austerlitz. Rundvandringarna i minnets landsändor precis som de i städer eller genom öppna landskap är aldrig passionerade till rusets grad, såsom Walter Benjamin tänker sig dem i sina anteckningar om flanören (i den första volymen av det ofullständiga, som en öppen stad, arbete om Paris på artonhundratalet, och även i den andra, Das Passagen-Werk, s. 1053), inte heller är de vittnen till förstörelsen som benjaminska änglar. Tvärtom utvärderar de den, beskriver dess resultat och bringar framförallt fram till ljuset dess gömda, glömda, förträngda märken. Det är kanske av den anledningen att Sebald undviker abstrakta tankar och analyser, det filosofiska sökandet och ifrågasättandet, jämförelser av begrepp, och istället föredrar beskrivningar och den ackumulativa presentationen av fakta. Mycket sällan är han intresserad av hur sanningen produceras, medan han alltid lockas av obestridda konstateranden om de fruktansvärda spår efter denna sannings misslyckanden i människans förhållande till världen. Han dokumenterar med precision och framlägger noggrant valda arkivsammanställningar. Hans horisontella berättelser har sällan vertikala skärningar. Berättarflödet avbryts inte av uppenbara ifrågasättanden. Det handlar dock om vidgande beskrivningar och bearbetade registreringar som talar genom tanken och till tanken, om tänkande detaljer av påtagliga förlopp i tid och rum, vilka utmanar tankeverksamheten. Det är omöjligt att vara en läsande flanör i Maurice Blanchots berättelser eftersom man där sjunker in i det vertikala framåtskridandet av hans tänkande. Sebald breder ut texter som städer och landskap, han skriver långa satser som innefattar många bisatser, tvärgator, stigar och gränder som avviker från huvudvägarna eller slingrar sig i deras periferi. Berättaren i "All'estero":

Hade man efteråt ritat in de vägar jag gått då skulle intrycket ha blivit att här hade någon på en på förhand given yta ideligen prövat nya passager och krumbukter bara för att ständigt återigen hamna vid randen av sitt förnuft, sin fantasi eller viljestyrka och tvingas vända om. (Svindel. Känslor, över. U. W., s. 125.)

Och så, i en stad eller ute på landsbygden vandrar och går flanören vilse i det som redan skapats och erbjudits. Han följer resultaten, avtrycken av andras tankar eller tanklöshet, absorberar och återger, och då och då och för en kort tid engagerar han sig i analysen av det han möter, begrundar allt som omger honom. Således kommer Sebalds få och korta, vertikala nedåt- (analytiska och begrundande) eller uppåtskärningar (intuitiva och hypotetiska) oförhappandes och fascinerar en mer än om man väntade på dem eller associativt anade dem. Flanören tänker inte under kringströvandets lopp. Om han gjorde det, hur skulle han kunna vara absorberande, hur skulle han kunna se vad som han möter utan att kollidera med träden på gatan, hur skulle han kunna visa sin kärlek till den plats som erbjuds honom? 


\title{
Chichester, 5 oktober 2012.
}

Tänkande beskrivningar även i Sebalds längre dikter eller i de mycket korta (som de från 2001 i boken For years now, vilka beledsagar bilder av Tess Jaray) ger läsaren möjligheten att engagera sig i begreppsliga utvidgningar eller, på flanörens manér, lita på hans personliga förtecknande uppfattningsförmåga. I diktsamlingen Över landet och vattnet (Über das Land und das Wasser, 2008, s. 39, som möjligen färdigställdes 1984), i dikten "Något i örat" (som talar om hjärtats död, den som år senare, genom aneurysm, fann honom i bilen nära Norwich) leder oss dessa beskrivningar fram till avgrundens dubbla varande:

\author{
Medan jag somnar \\ i soffan \\ hör jag på avstånd \\ gässen på radion \\ vässa näbben \\ för att läsa domen \\ Bladmögeln växer \\ i trädgården förlamningen \\ sprider sig \\ en lång rad \\ av minimala förskräckelser \\ jag känner blodet \\ under rötterna \\ av mina tänder \\ När jag vaknar \\ vinkar hjärtdöden \\ åt mig \\ från andra sidan \\ avgrunden
}

Kanske handlar det inte om avgrundens varande, kanske har avgrunden ett varande på ena sidan bara, den andra, medan dess varande på den här sidan förblir avgrundsdjupt, och därför upphäver det alla försök att tillskriva det bestämmande existentiella egenskaper. Vad är avgrunden och vad är dess andra sida? Kan det vara så att avgrundens andra sida inte alls är någon avgrund? Tvivelsutan närmar något konkret sig från andra sidan avgrunden, något definierbart och definitivt. Dödens hot. Ändå befinner poeten sig redan i en avgrund, där han nu upplever hur en negation sprider sig. Men skulle det handla om avgrunden utan denna negation, och som nu hotas av ytterligare en negation, en mer slutgiltig kanske? Har negationen från avgrundens andra sida redan trängt sig in medan poeten ligger och sover på denna sida, och hotar det som alltid för-existerat och 
som, lik en för-ontologisk öppenhet, underminerar metafysikens fundament och varje övertygelse som grundar sig i den? Är denna negation närmandet från andra sidan av ett slut, och även av slutet som egenskap, struktur och våld? Och avgrunden på denna sida, självgenererad, hur skulle den själv kunna bevara sig utan negationen som i sin yttersta form leder till maktfullkomlighet? Sebald vill utplåna maktfullkomligheten, själva fascismen och allt som skulle kunna återkalla den: ”Jag vill utradera fascismen ända ner till mitt namn. Jag använder endast initialerna på mina förnamn...” (Saturn’s moons, s. 354). Han vill inte ha rötter. Och av denna anledning vill han inte tillhöra något land, någon stad eller by: ”Ju längre jag bor här [i England] desto mindre känner jag mig som hemma. I Tyskland tror man att jag är född där, men jag känner mig minst lika främmande där. Helst vill jag nog bo på ett hotell i Schweiz” (Maya Jaggi, ”Recovered memories”, The Guardian, 22-9-2001). Flanören som inte vill ta eller bli tagen i besittning. Flanörens hem är de platser han far över. När han inte befinner sig på dessa platser är hans hem deras minnen. Berättaren av tragiska konflikter från det omedelbara men även avlägsna förflutna, av deras resonans i nuet, deras spår i minnet och i naturen, vars melankoli framkallar hans tragiska medvetenhet, hans uppfattning av det tragiska, insikten som kanske någon gång, och tack vare den fasa som Sebald målar upp, inte kommer att leda oss till våldsamma sammandrabbningar igen. Flanören som minns med opåverkat minne för att smidigt kunna avlägsna sig från dess innehåll och lika smidigt återvända till det. Sebalds språk, dess stil - inspirerad främst av tyska författare från artonhundratalet, vilka gav mer vikt åt det berättande språkets autonomi snarare än dess analytiska styrka eller känslomässiga tyngd, (Saturn’s moons, s. 369) - bevarar berättarens förnimmelseförmågor i en distanserad balans, odlar hans egenskap som en besökare som inte identifierar sig med tillståndet i världen han beskriver.

\section{På tåget till Växjö, 24 april 2008.}

En flock hjortar. Under våren 2008 läste jag Sebald på grekiska, i de värdefulla översättningarna av Giannis Kalifatidis och Ioanna Meitani. Sent på eftermiddagen i april 2008, från mitt fönster på vänstra sidan av tåget på spåret som förbinder Köpenhamn med Kalmar, i utkanten av en skog, bortom en grön äng mellan de små städerna Höör och Hässleholm, just när jag hade kommit fram till sidorna 192 och 193 av Utvandrade (s. 426 och 427 i den svenska översättningen) och hörde Max Aurach (som Sebald döpte om till Max Ferber i den engelska utgåvan) tala om våren 1945 i Manchester och om det "blekgröna parklandskapet” som försvann i djupet av "slätten”, där han "en halvtimme efter" solnedgången såg "en flock hjortar på väg in i natten", såg jag en flock hjortar stå och titta mot tåget. Jag såg dem samma stund som jag läste om Aurachs hjortar. Öde och tillfällighet, Max Aurach. Hjortarna förseglade hans beslut att acceptera sitt öde och bli kvar i Manchester. Ett ögonblick av evighet och samtidigt ett ögonblick utanför tiden i förhållande till tidens gång som han noterade runt sig. Och samtidigt sammanfallet av tiden i rörelse med tiden i orörlighet och med själva ödet. Och just då mitt eget sammanträffande i det ögonblick som romanens verklighet flöt samman med min egen 
verklighet. Och dessutom detta dubbla ögonblick av lycka. Är inte det som resenären som färdas genom landet på dessa delar av Europa ofta önskar sig, att få se en flock hjortar och uppleva en stunds frid som står för det korta avståndstagandet eller utträdet från tidens obevekligt strukturerade flöde? En bild med sorglösa hjortar, som samtidigt är ett ögonblick med sin egen tid. En på en gång episk och lyrisk scen som lätt kan skrämmas och upplösas av ett plötsligt ljud, av närvaron av något som inte harmonierar med den. Och därtill en melankolisk stund på grund av sin sällsynthet. Jag föreställde mig Max Aurach, men även Sebald själv, som en hjort, som en flock hjortar, som på distans begrundar förskräckelsen, förskräckelserna som människan har ålagt, det strukturerade flödets våld. Slumparna skapar villrådighet, försätter logos mekanismer i svårigheter och framkallar en egen logik. En logik utan logos, logos utan en logik. Sebald, som inte tror på Gud, kallar denna logos utan logos "metafysik":

När slående sammanträffanden inträffar har man alltid känslan att de måste betyda något. Men man vet inte vad. De är förmodligen fenomen som uppstår i livets utkant, där den så kallade verkliga världen kommer i kontakt med det metafysiska. Metafysiken är något om vilket man inte talar längre. Det anses vara löjligt, utan substans, meningslöst. Ändå är jag intresserad av metafysiska teman i ordets vidaste bemärkelse - och när jag säger det menar jag inte det i religiös mening, för det skulle vara mig främmande. Högst osannolika sammanträffanden, överlappanden med andra människors liv, saker som inte kan förklaras med ord förekommer under alla människors liv (Saturn's moons, s. 352).

Detta metafysiska tänkande utan sin religiösa dimension borde vi föreställa oss som ett tänkande utan logos styrande, befallande gester. Det tilldrar sig sådant som logos inte kontrollerar, som inte bestäms av en början och ett slut, och som ändå påverkar vårt förhållande till världen, det utvidgar det mot oväntade riktningar, nivåer och dimensioner. Fram kommer själva gåtfullheten, den oförklarliga inkongruensen mellan överraskande företeelser, händelser och samband. Det är platsen som formas av sammanträffandena, befryndad med, om inte densamma som, den som berättaren i Austerlitz beskriver (övers. U. W., s. 761):

Och när han [Austerlitz] nu hade träffat på mig här i baren på Great Eastern Hotel, där han aldrig i hela sitt liv hade satt sin fot förut, så ägde det, mot all statistisk sannolikhet, en häpnadsväckande, rentav tvingande inre logik.

Vi skulle kunna säga att Sebald, i likhet med Tomas Tranströmer till exempel, är en förmetafysisk, för-ontologisk författare eller en författare som övertänker rummet bortom metafysiken, de stunder som bryter det transcendentalas koherens. Därför vill han, när han inte stöter på slumparna, provocera fram dem (Saturn's moons, s. 279). Han skulle föredra en värld som består av tillfälligheter bara, således skulle han vara fri från varje följdriktig konstruktion, en värld (kosmos) som ett ordnande (kosmetik), skapad av alldimensionella, endogena, slumpartade harmonieringar, ett herakleitiskt land, där vi hälsas av "det obegripligt exakta trasslet av strån i en tova torrt gräs” (Austerlitz, s. 818, övers. U. W.). I intervjun med Joseph Cuomo (s. 97) kallas och uppfattas naturligtvis vår rationella värld av Sebald som ”nonsensical” och får mening tack vare tillfälligheterna: 
Jag tror att alla våra filosofiska system, alla våra religiösa system, alla våra konstruktioner, även de teknologiska, är byggda på det sättet, så att de har någon form av mening, vilken inte finns, som vi alla vet.

Det meningslösa, det som saknar logos, ger mening åt logos, det ologiska är anledningen att logos blir logisk, men inte som ett väsen som bestäms av översinnliga, systemiska regler, utan som en väv av oförutsedda innebörder. Det är väldigt intressant att fundera över faktumet att Sebald, trots att han förblev borta från det samtida dekonstruktionistiska tänkandet (han diskuterar det inte och kanske intresserar det honom inte), har mycket gemensamt med det. Jag anser till och med att han inte bara låter oss lämna bakom oss öppenheten såsom den diskuteras hos den sene Martin Heidegger, utan även nå längre än den ibland utmattande spänningen i de ifrågasättande (beroende av negationen, men med affirmationen som mål) utforskningarna hos Jacques Derrida.

\section{Kreta, Heraklion, juli 2013.}

Sebald skriver som en vandrare som med sina vandringar bejakar själva vandrandets funktion som öppnar för honom rummet bortom orsakerna till katastrofer; det är en öppenhet där sanningen har försvunnit redan innan varje ögonblick har passerat, mitt i ett ständigt uppdagande och en ensamhet som just i den stunden är lika mycket hans som platsens han korsar. Två ensamheter öppnar sig för varandra. Och flanören följer sålunda två parallella episka färdvägar, den som platsen och dess historia erbjuder och den som han skapar själv. I Sebalds fall täcks hans personliga vandringsvägar av melankolins särskilda patina som de destruktiva mänskliga handlingarnas märken har skapat ("Vår existens som art är inte legitim. Vi har organiserat vårt samhälle på ett sätt som hotar att bränna oss själva.” Saturn's moons, s. 351), men som samtidigt är euforins patina. Och detta beror på den bejakande kraft som denna kännedom döljer och som förvandlar honom till en annan form av liv, tar honom bortom den strukturerade tiden. Hans berättelser blir följaktligen inget annat än rader av ögonblicksbilder "för all evighet” eller försök att "skapa ytterst små reservoarer av tidlöshet” (Saturn’s moons, s. 352 och 353). Den patina genom vilken Sebald gör sina observationer täcker utan att vidröra de platser han vandrar på, den är (med hjälp av Benjamins tankar igen) som en smidig balkong, en sorts Saturnus ring, som ger honom möjligheten att sväva över världen utan att tillhöra den och utan att tillägna sig den. Till denna patina ger den rörlige Sebald ett till synes orörligt djup med hjälp av betraktelser (i förväg eller efterhand) och forskning i arkiv, och undersökning av historiska och teoretiska källor, så att den initialt så personliga berättelsen får sin episka dimension och dokumentets karaktär. Han känner inte behovet av att dra slutsatser eller undervisa med hjälp av historien, såsom Konstantinos Kavafis gör. Istället påminner han oss om Thanasis Valtinos då han rekonstruerar en version av verkligheten. Men liksom Kavafis nu, och i motsats till Valtinos som registrerar med hjälp av en essäistisk, objektiv iakttagelseförmåga, låter Sebald sina ord genomandas av melankoli (som dock ofta är defaitistisk och nedslagen hos Kavafis, medan den är lugnt frälsande hos Sebald). I den engelska volymen Campo Santo (2005, s. 24), där 
han talar om kyrkogårdar och döda människor på Korsika, uppspårar berättaren Sebald begravningskammare i olika delar av landet, såsom i "en olivlund fylld av ljusets och skuggornas rörelser.” Tankarna vandrar till en dikt av Valtinos i volymen Shismi fotos (Ljusspringa, 2001, s. 67, översättning Vasilis Papageorgiou och Lo Snöfall). Vi läser i den om skuggan från olika träd, bland dem olivträdets:

Däremot är olivträdets skugga

ytterst tunn,

gjord av cikadornas ljud

och silade soldroppar.

Ett broderi på sommarens hud.

Och Valtinos berättare ändrar takt och ton för att avsluta med det pragmatiska konstaterandet som ger ännu större emfas åt finessen i hans ord:

Trots sin ålder har olivträdet aldrig betungat jorden.

En likartad skugga har johannesbrödträdet också.

Valtinos står dessutom stadigt på jorden och avlägsnar sig inte från sin berättelses kärna, medan Sebald svävar över händelserna och fjärmar sig för att sedan återvända till dem och ändra dem lite innan han fjärmar sig igen från plats till plats, från tid till tid, från minne till minne, utan att följa någon plan, utan bara sin intuition för stunden samt slumparnas nyckfullhet. Och han kunde vandra runt oupphörligt, om han så önskade, han kunde fortsätta sitt kringströvande tills han hade fallit ner livlös, något som, skulle man kunna förmoda, alla flanörer känner och tänker, och kanske drömmer om. Och Sebalds vandrande läsare befinner sig i samma dynamiska situation. Hon kan lämna en av hans texter halvläst för att fortsätta läsa någon annan av hans böcker, hon kan återvända till den halvlästa och hoppas att det finns ofantligt fler sådana, hänförd av ord som fjärmar sig från sina meningar och blir till en mångdimensionell materialitet, en öppen fysisk plats utanför tidens gränser, en avgrund utan sin negativa semantiska last.

\section{Thessaloniki, 20 juli 2013.}

Från den ena melankolin, den som framkallas av historiens och naturens negativa händelser, stiger Sebald upp i den andra, den som orsakas av den tragiska medvetenheten om avgrunden, över vilken vår värld är byggd. Denna andra melankoli är samtidigt en eufori emedan den öppnar vägen till en bejakande inställning till världen, befriar logos från metafysikens negation, från våldet och orsakerna till dess uppkomst. Men denna eufori bör inte uppfattas som lycksalighet. Inte heller bör vi uppfatta melankolin som depression. I sin intervju med Martin Doerry och Volker Hage, där han avslöjar sin rädsla för det melodramatiska ("Ich fürchte das Melodramatische”, Der Spiegel, 12-32001), är Sebald tydlig: ”Melankolin är något annat än depression. Medan depressionen gör det omöjligt att tänka och kontemplera, tillåter melankolin - inte nödvändigtvis en 
trevlig situation i sig - en att kontemplera...” Om vi följer denna tankegång, kan vi säga att euforin, till skillnad från lycksaligheten, är en aktiv, skapande situation, en ändlös förståelse som inte låter minnet vila en stund. "Det är klart tror jag”, förklarade Sebald kort före sin död, "att de som inte har något minne har en mycket större chans att leva ett lyckligt liv" (Maya Jaggi, "The last word”, The Guardian, 21-12-2001). Sammanflödet av melankolin och euforin tar den distanserade patinas form som svävar strax över de händelser och fenomen som Sebald går genom, som "svävar en handsbredd över marken”. (Denna bild får vi av Sebald i Svindel. Känslor, övers. U. W., s. 199, och i Saturnus ringar, s. 658. Klädd i andra ord möter vi den i essän om Walser i Logis in einem Landhaus, 1998, s. 166, och i essän om Vladimir Nabokov i Campo Santo, s. 150 till exempel). I den molniga patinas och den kringsvävande avgrundens eufori (vi måste tveklöst någon gång hitta ett annat namn för avgrunden, ett som inte skrämmer och hotar, som ska kunna indikera den styrlösa oändligheten) vecklar världen (som kosmos) ut sig på ett slumpmässigt sätt så länge logos överger logos och avslöjar, medan den samtidigt njuter av den, ett arrangemang (en kosmetik) som vi, av andra skäl givetvis (och varför inte), kan identifiera i Jacques Austerlitz ord (övers. U. W., s. 791):

[...] men på sistone har jag också fått klart för mig varför en instans som går före eller står över min tankeförmåga och som tydligen med största förtänksamhet styr och ställer någonstans i min hjärna alltid har bevarat mig för min egen hemlighet och systematiskt hindrat mig från att dra de närmast till hands liggande slutsatserna och anställa mot dessa slutsatser svarande efterforskningar.

Vi befinner oss i rummet med sitt eget irrationella inre, där världen förblir öppen för att den är hermetiskt logosavvärjande, för att den inte låter logos strålar tränga in. Föremålen framträder här på det sätt som Austerlitz beskriver dem när han talar om mörkrummet och den fotografiska konsten (s. 818, övers. U. W.):

I huvudsak sysslade jag från första början med tingens form och slutenhet, ett trappräckes svängda linje, hålkälen på en stenportal, det obegripligt exakta trasslet av strån i en tova torrt gräs.

Sebalds texter har från sitt första ord samma egenskaper som sina inbäddade fotografier. De är inte beroende av förklaringar, av en angelägen meningsfullhet. De utvecklar en tidlöshet som vill överskrida både det onda och dess källor. Euforin i hans texter tar oss ut i ett ogrundat himlavalv som svävande avlägsnar sig samtidigt som den hänger kvar här omkring, den ställer oss i en kosmetik där Varat inte är något annat än en omätbar vävnad av opåtänkta harmonieringar och disparata sammanflätningar. Alltid med våra handlingars tragiska mörker hack i häl på oss:

I varje fall upptog mig under tiden därefter både minnet av den sköna rörelsefriheten och minnet av den förlamande fasa som åtskilliga gånger hade gripit mig inför de spår av förstörelse som även i denna avsides belägna trakt gick långt tillbaka i det förflutna. (Saturnus ringar, övers. U. W., s. 497.) 